\title{
No Forbidden Zone in 21st Century
}

Celebrating 20 years of the Hong Kong journal

\section{David Bartel}

Translator. Elizabeth Guill

\section{OpenEdition}

\section{Journals}

\section{Electronic version}

URL: http://journals.openedition.org/chinaperspectives/5576

DOI: 10.4000/chinaperspectives.5576

ISSN: 1996-4617

\section{Publisher}

Centre d'étude français sur la Chine contemporaine

\section{Printed version}

Date of publication: 30 July 2011

Number of pages: 66-73

ISSN: 2070-3449

\section{Electronic reference}

David Bartel, « No Forbidden Zone in 21st Century », China Perspectives [Online], 2011/2 | 2011, Online since 30 June 2014, connection on 24 September 2020. URL : http://journals.openedition.org/ chinaperspectives/5576 ; DOI : https://doi.org/10.4000/chinaperspectives.5576 


\title{
No Forbidden Zone in
}

\section{1st Century}

\author{
Celebrating 20 years of the Hong Kong journal
}

\author{
DAVID BARTEL*
}

\begin{abstract}
The Hong Kong journal Ershiyi shiji (21st Century) occupies a special place in the radical reconfiguration of the Chinese intellectual landscape that followed the traumas, both national and international, of 1989. On the occasion of its twentieth anniversary, we retrace the founding of the journal and the aspects that have made it unique in the world of the "thinking" press, and question the normalisation in China of the intellectual internationalisation of the first decade of the twenty-first century.
\end{abstract}

KEY WORDS: intellectual life, history of ideas, liberalism, postmodernism, nationalism, press, Hong Kong.

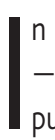
October 2010, the bimonthly Hong Kong journal Ershiyi shiji (二十 一世紀 - 21st Century) celebrated its twentieth anniversary with the publication of its $121^{\text {st }}$ issue. This would therefore seem a suitable occasion on which to retrace the history and the particularities that have enabled it to become and remain one of the cornerstones of the Chinese community's "thinking" press. Founded by a couple of historians, refugees in Hong Kong, and published by the Institute of Chinese Studies (中國文化 研究所 - Zhongguo wenhua yanjiusuo) of the Chinese University of Hong Kong (香港中文大學 - Xianggang zhongwen daxue, CUHK), and on the periphery of the People's Republic (PRC), the journal might have been simply a vain attempt to revive a dying Chinese liberal movement. However, Ershiyi shiji rapidly became a journal of reference in which Chinese intellectuals could reflect on, and debate, some of the intellectual conundrums that spread across China and the world throughout the 1990s, in the forefront of which were the globalisation of the economy and of capitalism.

Although the journal prints only 3,500 copies per issue, it nonetheless offers a special forum in which the intellectuals of Greater China can express contradictory opinions. In so doing, it echoes the "thinking press" in Continental China, whose best-known review, Reading (讀書 - Dushu) has a print-run of more than 100,000. (1) It is not unusual for authors to write for both publications and for the polemics to echo one another, within the limits that exist in the People's Republic. (2) Although Ershiyi shiji is difficult to find on the mainland outside university research centres, the most important articles are now invariably found on the Internet, which in China does not initiate debate so much as it offers an enormous resonance chamber for the exchange of ideas. ${ }^{(3)}$

The aim of this article is two-fold. Firstly it hopes, through tracing the history of a major scholarly journal, to review the survival of a liberal movement - associated with the Enlightenment in the 1980s - which, despite many difficulties, has left a lasting impression on Chinese society. Next, by retracing the intellectual issues of the late 20th century, we will attempt to outline the basic characteristics of a contemporary intellectual arena in which a renewed national story and a completely new relationship with a globalised world are being played out, overlap, and jostle one another. We will therefore begin by retracing the origins of the journal, which presupposes a detour via the careers of Jin Guantao (金觀濤, born in 1947) ${ }^{(4)}$ and his wife Liu Qingfeng (劉青峰, born in 1949), its joint founders. A long conversation with Chen Fangzheng (陳方正, born in 1939), key figure in the archaeology of the journal, threw light on the delicate period that led from the repression of 4 June 1989 to the founding of the journal and publication of its first issue in October 1990. We will see how the thinking that led to the creation of Ershiyi shiji in a sense foreshadows both the establishment of a part of Chinese cultural life in an intellectual periphery in the making, and the continuity of a liberal school of thought that met difficulties on the mainland. Indeed, whilst in the PRC the situation at the beginning of the 1990s remained relatively tense, a movement of intellectual emancipation had already been set in motion centring on the twin poles of Hong Kong and the Anglo-American academic diaspora. ${ }^{(5)}$

David Bartel is a doctoral student at CECMC (EHESS, Paris) and an associate researcher at CEFC. He is writing his doctoral thesis on the singularities of the careers of the intellectuals and historians jin Guantao and Liu Qingfeng.

1. Wang Xiaoming gives this figure in the "Dushu" entry in the Encyclopedia of Contemporary Chinese Culture (Routledge, 2009), p. 164. For Ershiyi shiji, circulation is a little less than 3500 , but the approximate figure has been confirmed by Liu Qingfeng. The exact figure remains confidential, however. (Email dated 13/12/2010)

2. The title of the present article is a direct reference to that of Zhang Yongle, "No Forbidden Zone in Reading? Dushu and the Chinese Intelligentsia," New Left Review, no. 49, January-February 2008, pp. 5-26.

3. For the Internet in China, two articles by Éric Sautedé are particularly instructive: "Les leurres de la modernité - Internet, information et crise du SRAS en China (The snares of modernity - Internet, information, and the SARS crisis in China)," Perspectives chinoises, no. 76, 2003; and more recently (April 2007) on the website of La vie des idées, "Une révolution sans illusion - Internet et liberté d'expression en Chine (A revolution with no illusions - Internet and freedom of expression in China)," http://www.laviedesidees.fr/Une-revolution-sans-illusion.html (10/11/2010)

4. We have persisted in giving the date of birth in brackets of many of the people mentioned in this text. The traumatic events of the second half of the twentieth century and the speed of change over the last 20 years means that communities with shared experiences change very quickly, and generations who are very close intellectually often have very different experiences of China and the world. We would like to take the opportunity here to thank anonymous readers and the editorial team of China Perspectives, whose advice was extremely valuable in writing this article.

5. Du Weiming, "Cultural China: The Periphery as the Center," Daedalus, Spring 1991. 


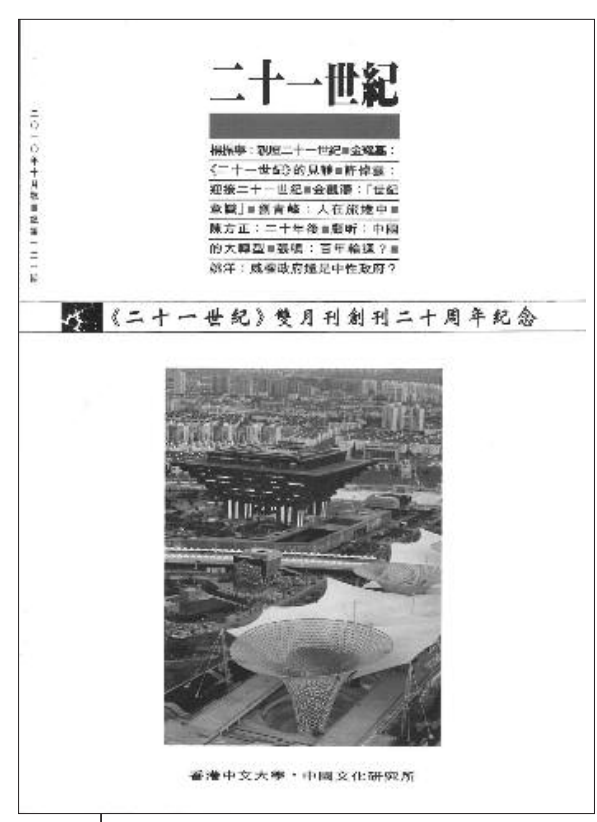

Ershiyi Shiji celebrates its 20th anniversary, October 2010.

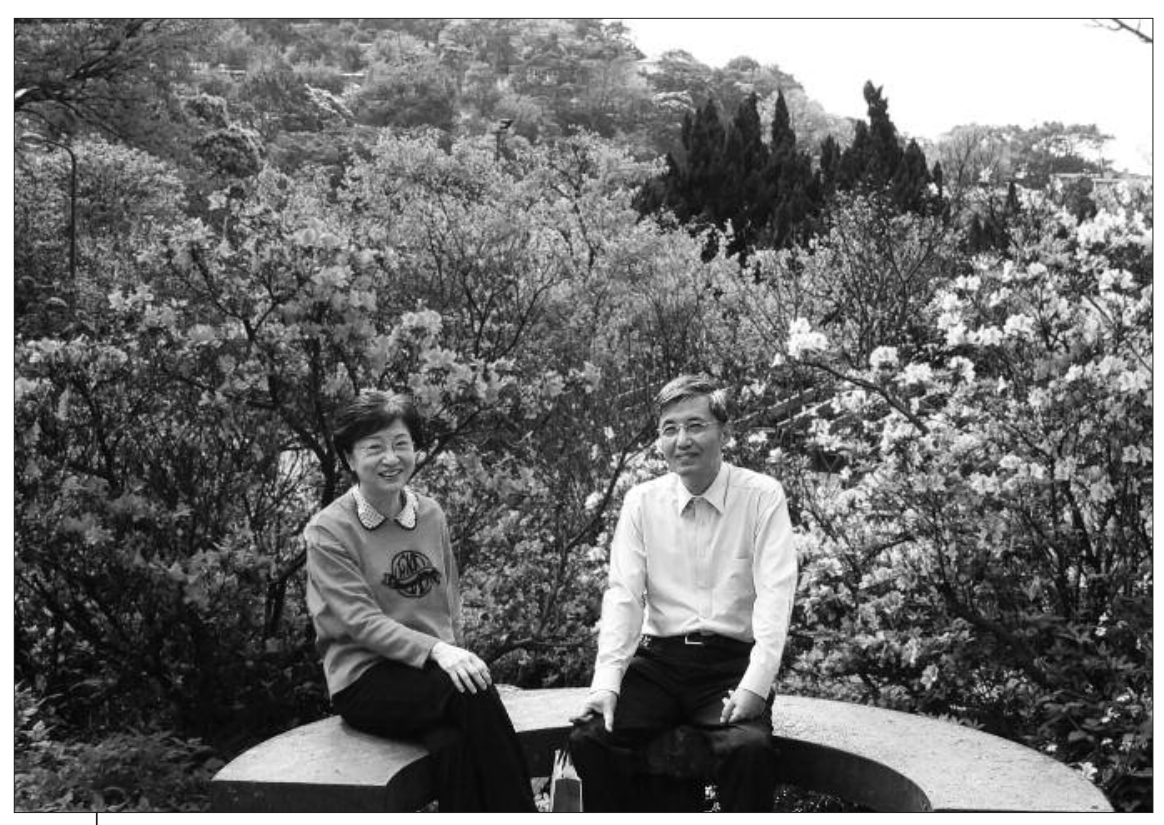

Jin Guantao and his wife, Liu Qingfeng. ๑) Liu Qingfeng
Next, although it would be impossible to deal in detail with all the elements that over the last 20 years have made China what it is today, we will follow the thematic classification of the main intellectual developments that structured thinking in China in the 1990s, as put forward by Beijing philosopher and historian Xu Youyu (徐友漁 born in 1947), an important figure in Chinese liberalism and a regular contributor to the journal. (6) This classification, though necessarily incomplete and schematic, seems nonetheless to give both an interesting overview of the journal's eclecticism and at the same time, a fairly clear idea of the structure and relationships between the great debates that have taken place in China since the end of the Cold War.

Lastly, we will try to see where these polemics have led by observing the contemporary intellectual scene, for does not the beginning of the twentyfirst century correspond to a form of normalisation that focuses on several essential ideas emanating from the many post-1989 crises?

\section{Jin and Liu, the young guard of cultural activists}

At the origin of the Ershiyi shiji adventure we find a couple of intellectuals: Jin Guantao and Liu Qingfeng. ${ }^{(7)}$ Born with the People's Republic, they were prevented from attending university during the Cultural Revolution (1966-1976) and are part of the loose group of intellectuals who consider that rather than having broken away from pre-1949 China, the "New China" is simply the last stage in a long historic process in which the harmful and alienating influence of a traditional holistic ideology persists. They see in the rigid dogma of Marxism a renewed version of a Confucianist rigour they deem "feudal" (封建). ${ }^{\left({ }^{8}\right)}$ It was for this hypothesis of the stability of the ideological structures of traditional Chinese society that from the beginning of the 1980s, Jin and Liu were to become known. ${ }^{(9)} \mathrm{A}$ scientist by training, Jin Guantao supported his argument with the vocabulary of theories in vogue at the time, ${ }^{(10)}$ which gave his articles a modern and sci- entific aura that was poles apart from the revolutionary romanticism of the previous decades. In this way he succeeded in publishing a work that bypassed the conventions of traditional Marxist historiography and alienated itself from the sycophancy of orthodox historiography, the exclusive and beloved preserve of the Party. ${ }^{(11)}$ Although the distribution of Jin Guantao and Liu Qingfeng's first publications remained confined to a narrow readership, once their essay Xingsheng yu Weiji (興盛與危機 - Crisis

6. For an example of Xu Youyu's work, see "The Chinese Cultural Revolution: Concealed History and Tobe-discovered Memory," in History and Memory: Present Reflections to Build Our Future, Macau, Mateo Ricci Institute, 2008, pp. 447-60.

7. Liu Qingfeng tells of her meeting with Jin Guantao in a novel, which takes the form of an exchange of letters between friends and shows the confusion of a generation faced with the state of their country and their hopes for change. Jin Fan (Liu's pen-name), "Gongkai de qingshu" (Open love letters), original 1972 manuscript version, published in Women (We) a non-official paper in Hangzhou. Published later in Shiyue (October) in 1980, then again in Shiyue wenxue congshu (October's literary collection), Beijing, Beijing chubanshe, 1981. The novel is available on the Internet (http://www.shuku.net:8082/novels/dangdai/ publicqingshu/publicqingshu.html) (29/11/2009). The novel created a wave of intense emotion well before scar literature (shanghen wenxue); see:Tan Mei, "Nianqing yi dai de renshengjia 'Congkai de qingshu' yinqi de zhenglun" (A young humanist generation: the polemic surrounding "Open Love Letters"), Zhengming, no. 34, Hong Kong, August 1980. Liu Qingfeng refers to this episode in an interview given to Shanghai Culture, the journal of the Institute of Literature of the Shanghai Academy of Social Sciences, no. 74, vol. 3, 2009, pp. 96-101.

8. Jin Guantao gives an account of his intellectual awakening in a biography, Wode zhexue tansuo (My philosophic exploration), Shanghai, People's Press, 1988; it was then published in Taipei, Fengyun Shidai, 1989, and lastly in Beijing by New Star Publishing, 2005, under the title Xitong de Zhexue (Philosophy of systems).

9. Jin Cuantao and Liu Qingfeng, "Zhongguo fengjian shehui de jiegou - Yige chaowending xitong" (Structure of feudal Chinese society: A hyperstable system), Guiyang shifan daxue wenxuebao, vol. 1, no. 2, 1979. The article became an essay five years later, Xingsheng yu Weiji - lun Zhongguo fengjian shehui de chaowending jiegou (Crisis and Prosperity: The hyperstability of the structures of feudal Chinese society), Changsha, Hunan renmin chubanshe, 1984. The essay has been regularly republished since in Taiwan and Hong Kong. It is worth noting that after 20 years of being banned, this first essay and other writings by jin and Liu were once again published in the PRC by Falü chubanshe (Law Publisher) in Beijing.

10. Cybernetics, set theory and systems analysis have since, in China as elsewhere, fallen into disuse. They are known in China under the term "three old theories," laosanlun.

11. Although the hypotheses of jin Guantao have been widely criticised from an academic point of view, one might question whether their interest was merely academic. See: Ye Xiaoging, "Patriotism versus Intellectual Curiosity: Jin Guantao's Approach to Chinese History," in Gloria Davies, Voicing Concerns: Contemporary Chinese Critical Inquiry, Lanham, Rowman \& Littlefield, 2001, pp. 185-98. 
and Prosperity) was published in 1984, the split between reformists and conservatives was from then on clearly defined. Published at the crossroads of a publishing market in its infancy and the expectations of a curious public, the book, keen to respond to the reforming impulse set in motion by the highest authorities, was a success. ${ }^{(12)}$

\section{Institutional support and collaborators}

To ensure the publication of this essay under conditions that suited them, Jin and Liu, with the active complicity of the historian Bao Zunxin (包遵信 1937-2007), were behind an attempt at fostering an autonomous civil society that was unique in the history of the People's Republic: the founding of the book series "Towards the Future" (走向未來叢書 - Zou xiang weilai congshu). It was a fertile breeding-ground. Those born after 1949 had grown up in a highly dogmatic, culturally arid world, a world that some even considered relatively boring. ${ }^{13)}$ The number of publications fell from 27,000 in 1957 to 600 in 1967. In 1957 there were 600 periodicals; only 20 remained in 1967. ${ }^{(14)}$ In the gradual opening-up of the country after 1978, the failure of the Chinese Communist scheme became clear in the light of Western opulence, although the latter had already been affected by economic crisis. Young people were eager for new ideas to solve the country's problems. At the same time, the economy was slowly emerging from the rigidity of the Plan. As part of the same movement, the embryonic publishing market benefited from the support of middle-ranking bureaucrats who had confidence in the young guard of cultural activists. These cadres were apparatchiks, directors of academic institutions, directors of research institutes, and editors of official papers. They were often close to the reform movement of Zhao Ziyang (趙紫陽 1919-2005) and were open-minded enough to feel that Chinese society needed to develop. Yu Guangyuan (于 光遠 born in 1915) was amongst them. A student in physics who joined the Party in 1935, hero of the anti-Japanese resistance, and a translator of Engels, in 1949 he became head of the scientific section of the Department of Propaganda, and Party secretary of the Philosophy and Social Sciences Division of the Academy of Sciences. When the Division expanded in November 1977, becoming the Chinese Academy of Social Sciences (中國社會 科學院 - Zhongguo shehui kexueyuan), he was appointed Vice-President. That same year, together with several colleagues, he decided to relaunch the Journal of Dialectics of Nature (自然讋證法通訊 - Ziran bianzhengfa tongxun), a newsletter originally specialising in the philosophy of sciences, the publication of which had been interrupted during the Cultural Revolution. The journal's editor-in-chief, Li Baoheng (李保恒 born in 1922), then decided to hire jin Guantao - a young physics and chemistry teacher at the time - to work on this national paper. Very quickly, the Journal exceeded its initial ambition. By taking an interest in all scientific innovation, it began to attract many young talents in an atmosphere of freedom that prefigured the 1980s. These young 30-year-old intellectuals used the Journal of Dialectics of Nature as a first staging-post in the publication of their new optimistic, scientific, and rational ideals. ${ }^{(15)}$ However, the marked heterodoxy of their work soon incited them to found their own paper.

\section{"Towards the future"}

With the complicity of a group of reformist cadres in sympathy with the optimistic energy of the young couple, and after several abortive attempts to create a journal, Jin, Liu, and Bao finally managed to create an adminis- trative framework at the limits of socialist legality that enabled them to found a series of books and retain complete control of its content and editorial line. ${ }^{(16)}$ To publish a series of books without the control of the Party, in a country that had barely emerged from one of the twentieth century's strictest totalitarian regimes, was an unique success that was to serve as a model for the "book series craze" (業書熱 - congshure) that was to feed the many debates on Chinese culture in the second half of the 1980s. In 1984, when the first series of books in the "Towards the Future" collection was published, the debates between the reformers led by Hu Yaobang (胡耀邦 1915-1989) and then Zhao Ziyang, and the conservative old guard led by "the immortal" Chen Yun (陳雲 1905-1995), took on a different aspect. The division had been clearly established and was to leave its mark on the end of the decade. The response to the translated works and essays of the young 30-year-old intellectuals aroused people's curiosity and stuck in their minds. ${ }^{(17)}$ The Sichuan People's Press reprinted the works continuously. ${ }^{(18)}$

The Future group is generally associated with two other groups of intellectuals: firstly, "Culture: China and the World" (文化 : 中國輿世界 - Wenhua: Zhongguo yu shijie), founded by Gan Yang (甘陽 born in 1952), and secondly, the "Academy of Chinese Culture" (中國文化書院 - Zhongguo wenhua shuyuan), an institute that offers seminars and lessons directed in particular towards the renewal and the spreading of national studies (國學 - guoxue) ${ }^{(19)}$ and associated with the guardian figure of Liang Shuming (梁漱溟 1893-1988). Without going into detail, it must be said that the Futurologists stood out as much by virtue of the wide range of subjects they tackled as by their avowed ambition to make their publications accessible to as many people as possible. (20) This high-quality "popularisation" approach, the aim of which is to educate as many people as possible, has been a constant thread in Jin Guantao's career.

\section{Exile in Hong Kong}

In 1987, at the height of their fame, the couple was invited to Hong Kong for the first time by Chen Fangzheng, Director of the Institute of Chinese

12. Chen Yan, L'éveil de la Chine (The Awakening of China), La tour d'Aigues, éditions de l'Aube, 2002, p. 89.

13. For boredom amongst a certain section of Chinese youth in the 1970 s, see the memoires of the writer Yu Hua in La Chine en dix mots (China in ten words), Paris, Actes Sud, 2010. For someone who was a young adolescent at the time and unaware of what was at stake, "wrestling matches" and fights relieved a daily life described as very dull.

14. Jin Guantao and Chen Fangzheng (Chen Fong-ching), From Youthful Manuscripts to River Elegy, Hong Kong, CUHK Press, 1997, p. 126.

15. To gain an idea of the first publications, see Jin Guantao, Fan Hongye, and Liu Qingfeng, "Kexue jishu jiegou de lishi bianqian - lun shiqi shiji hou zhongguo kexue jishu luohou yu xifang de yuanyin" (Historical development of the scientific and technical framework: Discussion on the reasons why China lagged behind the West in terms of technology after the 17th century), Journal de la dialectique de la nature, no. 5, Beijing, 1982. An English version of this article can be found in Fan Dainian and Robert S. Cohan (ed.), "Chinese Studies in the History and Philosophy of Science and Technology," Boston Studies in the Philosophy of Science, vol. 179, Dordrecht, Boston, Kluwer Academic Publishers, 1996.

16. All the details of the administrative structure can be found in Jin Cuantao's only book published in English and co-written with one of the key players in the founding of Ershiyi shiji. Jin Guantao and Chen Fangzheng, opus cit. On the role of Bao Zunxin and his gradual eviction, ibid., pp. 114 and 209.

17. Translations of Douglas Hofstadter, Fritjof Capra, and Max Weber appeared, to name but three. All the titles published in the collection can be found in Edward X. Gu, "Cultural Intellectuals and the Politics of the Cultural Public Space in Communist China (1979-1989): A Case Study of Three Intellectual Groups," The Journal of Asian Studies, vol. 58, no. 2, 1999, pp. 404-406.

18. Chen Yan, op. cit., pp. 86-97.

19. China Perspectives devoted issue number $2011 / 1$ to the renewal of national studies

20. Michel Bonnin and Yves Chevrier, "The Intellectual and the State: Social Dynamics of Intellectual Autonomy during the Post-Mao Era," The China Quarterly, no. 127, September 1991, pp. 569-593. 


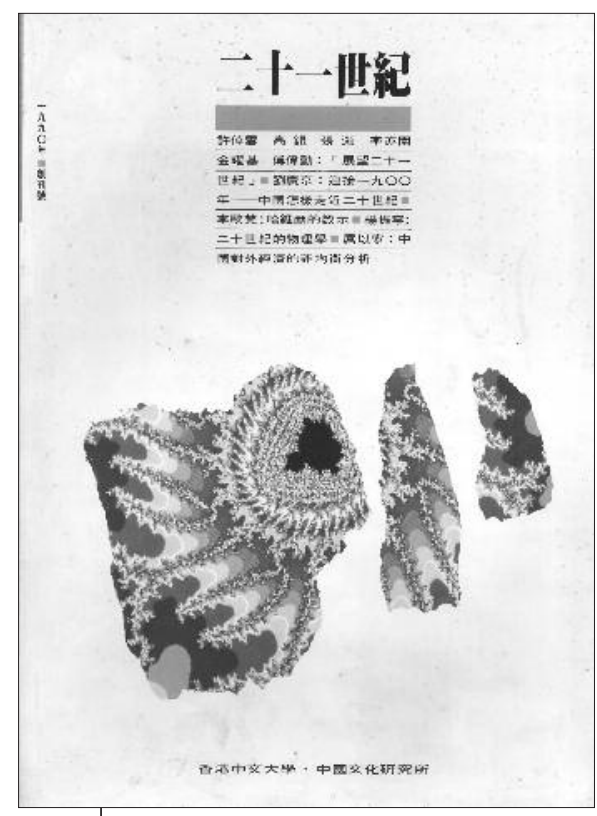

"For the cultural construction of China," cover of the first issue of Ershiyi Shiji, October 1990.

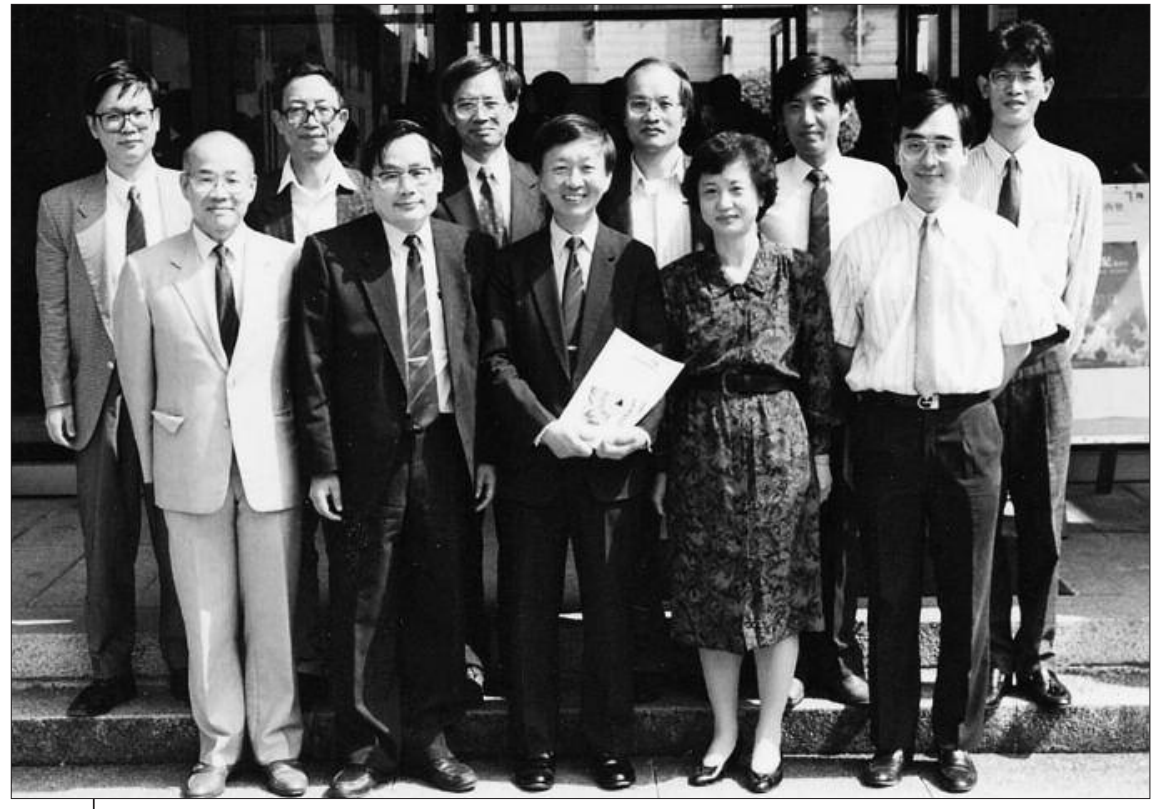

The staff and some editorial board members of 21st Century at its inauguration on 27 October 1990: Liu Qingfeng (front row), Chen Fangzheng (front row second from left), and jin Guantao (back row, second from right). ๑ Chen Fangzheng
Studies (ICS). In 1986, Chen had taken over the reins of the Institute (founded in 1967) with "the firm intention of modernising an institution that was gently ticking over with the traditional Chinese activities of the time: archaeology, literature, translation of the classics, and divinatory inscriptions." (21) He then travelled frequently with the aim of extending the visibility of the Institute worldwide. He returned to Harvard, of which he was a graduate, and met the historians Ezra F. Vogel (傅高義 born in 1930), John K. Fairbank (費正清 1907-1991), and the philosopher Yu Yingshi (余英時 born in 1930). By inviting Jin Guantao and his wife, he was attempting to open the Institute up to a mainland China undergoing an intellectual reawakening.

Far removed from the already considerable radicalisation of the younger generations, Jin and Liu and their contacts, who were very familiar with the workings of the Party-State, still believed at the time that reform could only come from within the system itself. They remained convinced that the system could be modified from the inside and that they would drive the country forward. Contrary to the countries of Eastern Europe, the public arena was not seen as a place in which to break free from the authority of the state, but to reform it. This was a Chinese particularity that led certain observers to consider as inevitable the failure of all future attempts at institutionalising civil society based on the Habermassian model, outside the machinery of state and extraneous to its power structures. (22) Invited again for a period of six months, Jin Guantao and Liu Qingfeng arrived in Hong Kong in April 1989, just a few days before the death of Hu Yaobang. They returned to China to participate, in an extremely tense atmosphere, in a conference at Wofosi, at the gates of Beijing, for the 70th anniversary of May Fourth 1919, but it was in Hong Kong that they would live through the dramatic events of June Fourth. ${ }^{(23)}$ After Chen Xitong (陳希同 born in 1930), then Mayor of Beijing, accused them of being amongst the "black hands" of the 1989 democratic movement, it rapidly became clear that it would not be possible for them to return in the near future. ${ }^{(24)}$
In December 1989, the agitation created by the role of Hong Kong in the evacuation of dissidents finally calmed down, but for Jin, Liu, and Chen, in this return to routine, one question remained: what was to be done to prevent the decade's humanist upswell and the undisputed intellectual impulse that accompanied it from disappearing? Together with Ambrose King (金耀基 - Jin Yaoji, born in 1935), a Taiwanese sociologist, the decision was taken to create a journal. To consolidate the academic foundation of the project, the four decided to appeal to the Chinese intellectual diaspora, in a supranational movement that prefigured the opening up of the Chinese world to its academic margins and in particular, Anglo-Saxon academia. (25) Thanks to the celebrity of the players they recruited, funds were quickly amassed. The technical difficulties linked to creating a journal were also quickly resolved. So on 27 October 1990, a journal appeared that opened with the catch phrase: "For the cultural construction of China" (為了中國的 文化建設 - Weile Zhongguo de wenhua jianshe), (26) a slogan that served as a title for Chen Fangzheng's editorial.

21. Interview with Chen Fangzheng, 19 November 2010, Hong Kong.

22. Laurence Weerts, "Quatre modèles théoriques pour penser la société civile dans l'ordre juridique international" (Four theoretical models for understanding civil society under international law), Report presented to the closed seminar Société civile et démocratisation des organisations internationales, 28 and 29 May 2004 at the free university of Brussels, p. 29 of the Internet version (http://www.ulb.ac.be/droit/cdi/fichiers/modeles_theoriques.pdf). See also: Michael B. Frolic, "StateLed Civil Society," in Timothy Brook and Michael B. Frolic (ed.), Civil Society in China, New York, M.E. Sharpe, 1997, p. 51. On the absence of an autonomous "buffer" between the state and society and its replacement in China by an "authority principle" in place of a public sphere, see Yves Chevrier, "L'historien politique et la Chine: Quelques réflexions" (The political historian and China: Some thoughts," Journal des anthropologues, no. 92-93, 2003, pp. 6 sq. (of the electronic version).

23. Jin Guantao and Chen Fangzheng, op. cit., pp. 259-69.

24. Chen Yingxiang, Dégel de l'intelligence en Chine 1976-1989 (Thaw of intelligence in China 1976-1989) Collection Témoins, Paris, Gallimard, 2004, p. 346. Chen Xitong was expelled from the Party in 1997 and was sentenced to 16 years in prison for corruption in 1998.

25. Du Weiming, op. cit.

26. Chen Fangzheng (ed.), Yu Zhongda yitong chengzhang (Growing up with CUHK), Hong Kong, CUHK Press, 1998, p. 117 


\section{The 1990s according to Xu Youyu}

To try to visualise the way in which the intellectual landscape was reconfigured and to gain a clear understanding of the close parallels between the journal and the Chinese world at the beginning of the twenty-first century, let us go back in time a little with the Beijing philosopher and historian Xu Youyu to what he considered to be the five major elements of the intellectual restructuring that followed the double trauma in 1989 of the repression in Tiananmen Square and the end of the Cold War following the collapse of the Communist bloc. (27) Xu Youyu, in the few pages he devotes to the twentieth anniversary of the journal, draws up a five-point table that seems to us significant, coming as it does from a well-known player on the intellectual stage, appreciated for his rigour and the constancy of his commitment. (28)

(1) Firstly, immediately following the 1980s and the repression of the student movement, intellectuals examined with hindsight their own vacillations between radicalism and conservatism, between their passion for "the spirit of May Fourth" (五四運動精神 - wusi yundong jingshen) and their fear of "troubles" (動亂 - dongluan). In the pages of Ershiyi shiji, starting with its second issue (December 1990), a change of direction occurred condemning the radicalism of the 1980s as heir to the same attitude that pushed the first modern radicals to embrace Marxism-Leninism rather than the liberal pragmatism defended by Hu Shi (胡適 18911962) at the same time. For the Sino-American historian Yu Yingshi, the twentieth century was the "most sombre" period in the history of the Chinese nation. The condemnation of Communism was categorical. In the same issue, Du Weiming (杜維明, born in 1940) raised the question of the responsibility of those intellectuals who by allowing traditional culture and society to disappear have placed themselves on the sidelines of the body politic. (29) For the authors of Ershiyi shiji, after the thirst for freedom expressed in a sometimes rather chaotic manner over the preceding decade, it was time to revert to an attitude of greater pragmatic realism towards conditions in China, whilst at the same time reinforcing the move towards the professionalisation of the academic world begun in the PRC towards the end of the 1980s. ${ }^{(30)}$ In the same issue, Jin Guantao reiterated this view in his analysis of the place occupied by utopia ( 鳥托邦 - wutuobang) in Chinese culture. He added a subtle, yet significant qualifier, however: in his view, utopia was maintained in China by a type of political pan-moralism, which from the Great Unity (大同 - Datong) to the "benevolent government" (仁政 - renzheng), propelled the Chinese into the catastrophes of the Great Leap Forward and the Cultural Revolution. ${ }^{(31)}$ Jin Guantao is part - as we have seen - of an intellectual movement that regularly analyses the China of today in the mirror of history and tries to throw light on the structural links that may exist between past and present. ${ }^{(32)}$

(2) It very soon became clear to the authors of the journal that nationalism and its political instrumentalisation had become the only ideological horizon the government could rely on. From 1992 onwards, therefore, the journal took an interest in the building up, development, and use of modern nationalism. The ICS organised an international conference on the theme of "Nationalism and Modernisation in China," publishing most of the speeches in two special issues of Ershiyi shiji (no. 15 and 16, February and April 1993). ${ }^{(33)}$ The question of nationalism re- mained, moreover, a central issue for the journal that was the first to publish, as early as 1993, the translation of a famous article by Samuel Huntington. Over and above a hypothetical "clash of civilisations," the article foreshadowed the present day and the appearance of a paradoxical tension between a progressive opening up to the world and the ethnocultural assertion of identity characteristic of contemporary societies. (34) It was a time when China's relations with the rest of the world were very tentatively becoming normalised as a result of a difficult, often polemical examination of the relationship between the Chinese and the Western "Other." Within the criticisms of the intellectual arsenal of Western modernity - essentially the product of eighteenth and nineteenth century Europe - a qualitative change in critical thinking was at work. "Liberalism," "constitutionalism," and "democracy," as well as "Marxism," "socialism," and "tradition"; all the categories of the twentieth century were reviewed and reinterpreted in the light of a modernity that was now seen as truly Chinese. In this decisive movement, they were the object of a major semantic shift that allowed them to move from Chinese characteristics (中國特色 - Zhongguo tese) of foreign ideas to an autonomous, independent, and indigenous Chinese model (中國模 式 - Zhongguo moshi). ${ }^{(35)}$

(3) The development of the rhetoric of nationalist arguments itself became indissociable from another movement that was seeking, at first through literary criticism, to deconstruct the presuppositions and unspoken issues of the debates of the 1980s. The journal initiated the polemics and quarrels that were to mark the intellectual community in China after 1989. Positions on these questions of language clearly stemmed from clashes between the old guard of intellectual liberals, educated in ideals of freedom and progress and active during the 1980s, and a new generation of intellectuals and writers who not only had no links to the Chinese "Enlightenment" (啟蒙運動 - Qimeng yundong), but quite simply ignored or even openly (and vigorously) condemned it.

27. Xu Youyu, "Women xuyao zhege sixiang wenhua kongjian" (We need this cultural space for thought), Ershiyi shiji, no. 121, Hong Kong, pp. 42-43.

28. See also the speech made on the eve of the 20th anniversary of the events of 1989, which appeared in the web review Rue89. http://www.rue89.com/2009/06/04/1989-2009-les-heritiers-de-tiananmen-reclament-la-democratie?page=0\#comment-895417 (04/08/2011).

29. Yu Ying-shih, "Daicongtou, shouhe jiushanhe" (Picking up the pieces for a new start), Ershiyi shiji, no. 2, December 1990, and "Zhongguo zhishifenzi de bianyuanhua" (The marginalisation of Chinese intellectuals), Ershiyi shiji, no. 8, December 1991. Du Weiming, "Huajie qimeng xingtai" (Going beyond enlightenment syndrome), Ershiyi shiji, no. 2, December1990.

30. Xu jilin, "Qimeng de mingyun" (The destiny of enlightenment), Ershiyi shiji, no. 50, December 1998.

31. The article "Zhongguo wenhua de wutuobang jingshen" (The utopic spirit of Chinese culture) was republished in jin Guantao and Liu Qinfeng, "Mao Zedong sixiang yu ruxue" (Maoist thought and Confucianism), Taipei, Fengyun sichao, 2006, pp. 37-58.

32. In the same review (see preceding note), the same authors have written an article that is emblematic of this movement, and was first published in 1988: "Zhongguoshi de shehuizhuyi yu chuantong - lun Zhongguo xiandai zhengzhi wenhua de xingcheng he fazhan" (Chinese Socialism and tradition: On the formation and development of modern Chinese political culture), pp. 21-37.

33. The proceedings of the conference were published soon after: Liu Qingfeng (ed.), Minzuzhuyi yu Zhongguo xiandaihua, Hong Kong, CUHK Press, 1994.

34. Samuel Huntington's article "Wenming de chongtu?" (The clash of civilisations?), published in Ershiyi shiji, (no. 19, October 1993), is symptomatic of this tension between globalisation and nationalism. The article, published first in English in Foreign Affairs in 1993, had already attracted fierce polemics.

35. It would not be possible to go into all the details of these many subjects. One can, however, consult the journal's highly efficient index on its Internet website: http://www.ics.cuhk.edu.hk/ $\mathrm{rcccc} / 21 \mathrm{c} /$ index/ (27/05/2011). For a more general overview of this movement, see Tao Dongfeng, "Cong huhuan xiandaihua dao fansi xiandaixing" (From the call to modernisation to reflections on modernity), Ershiyi shiji, no. 53, June 1999, pp. 15-23. No. 121 of October 2010 devotes an entire feature to it entitled "Reflections on the Chinese model." 
Dismayed by the success of popular writers - of whom Wang Shuo (王朔 born in 1958) is an illustrious example ${ }^{(36)}$ - these liberal intellectuals raged against the new mass culture, source of materialistic alienation that transmits the cultural "hooliganism" (流讯文化 - liumang wenhua) of lacklustre literary heroes with no ideals, created by authors who openly declared their financial ambitions in an expressly cynical stance. These writers seem poles apart from the disinterested humanist spirit (人文精神 - renwen jingshen) defended by advocates of a more fundamentally positive literature. ${ }^{(37)}$ On the other hand, the writer Wang Meng (王蒙 born in 1934), former minister of culture and figurehead of the intellectual opening-up of the 1980s, defended mass culture, in which he saw the very expression of the modernity so keenly sought in the 1980s. ${ }^{(38)}$ For leftist critics, however, the condemnation was categorical, since:

\section{Intellectuals lament the priority of money, moral corruption, and} the loss of social order in a commercialised society [on the one hand, but they] cannot avoid acknowledging that they are situated in this very process of modernisation - as commercialisation - that was formerly their goal. (39)

And these polemics on the amoral values of popular culture, the aims of literature, and the ultimate concerns (終極關懷 - zhongji guanhuai) of the intellectual community were quite naturally transformed into an examination of the presuppositions of the language in which the debate was developing and of the ideological weight of what it left unsaid. So between the launch of the journal and the mid-1990s, from issue to issue, a new way of seeing, thinking, and talking about China was created.

One might perhaps date the coming to maturity of the rhetorical uses of postmodern and postcolonial theories in the pages of the journal - and on the Chinese scene in general - from the reactions provoked by a special issue of the journal Modern China dated January 1993. (40) This provided an opportunity for a new generation of intellectuals, academics versed in the practice of literary criticism, to challenge the fundamentals of their predecessors' ideals. By highlighting the negative view of the ideals of progress and modernity in the writings of Michel Foucault (褔柯 - Fuke, 1926-1924) and other fashionable thinkers, the new generation of intellectuals made these writings lose the critical force they had held in the 1980s against the discourse of power. ${ }^{(41)}$ However, this erosion of resistance carried within it an ambiguity that gave birth to two new trends: on the one hand, the critical stance permitted in China by knowledge of imported theories was a strategic means of holding power at a distance, ${ }^{(42)}$ and on the other, a certain degree of rallying took place to the views of political authorities who had succeeded in brilliantly co-opting this intellectual renewal to nourish the theoretical poverty of the official national discourse. ${ }^{(43)}$ The arrival of "postisms" (後學 - houxue) in the debate was to extensively occupy the pages of Ershiyi shiji in the mid-1990s. (44)

There was, for example, the critic Zhang Yiwu (張頤武 born in 1963) from Beijing, who condemned the contemporary anxiety engendered by the loss of the humanist spirit of the preceding period as elitist resistance to mass culture, a resistance that in his opinion remained blind to the democratic potential of popular culture. ${ }^{(45)}$ The verdict was all the more severe since he at the same time attacked the iconoclastic heritage of 4 May 1919, upon which colonial and pro-Western literature had been built, and which for him was characteristic of Chinese culture in the period 1920-80. ${ }^{(46)}$ Other authors of the same period seem nonetheless to understand very clearly the link between postisms, cultural studies, and state nationalism in third world countries. They warned against the instrumentalisation of the emotional moment linked to the idea of Nation and its potentially explosive populist exploitation. ${ }^{(47)}$

So as we can see, imported textuality had, in the Chinese debate, broken free of its original literary and aesthetic links to enrich the field of history and politics. ${ }^{(48)}$ It was an opening-up of the Chinese world that rather paradoxically corresponded in the People's Republic with a turn away from the new national narrative, made possible by the immense success of translations of the classics of postcolonial literature. ${ }^{(49)}$ It might be said that reading - sometimes rather hastily - Edward Said's classic had a considerable effect on the universities of the former colonies. ${ }^{(50)}$ Young Chinese intellectuals rushed into this breach. The liberating effect of this new subjectivity, introduced by a theoretical enrichment, against the Western demand for objectivity resulted in the elimination of one of the poles of the China/West binarism, or at least, put it into perspective. However, this challenge to Western cultural hegemony necessarily led to a problematic examination of Chinese cultural subjectivity that was all the more complex since it could easily be appropriated by narrow nationalistic arguments. ${ }^{(51)}$ The links between this triple phenomenon - mass culture, "post" theories, and globalisation/nationalism tension - has proved fundamental for understanding how the Chinese intellectual landscape was redrawn after

36. Wang Shuo, Please Don't Call Me Human (Qianwan bie ba wo dang ren), London, No Exit Press, 2000 (trans. Howard Goldblatt - first edition in Chinese: 1989).

37. See for example, Chen Pingyuan, "Jinbainian Zhongguo jingshen wenhua de shiluo" (The decline of the elite culture in China in the last century), Ershiyi shiji, no. 17, June 1993.

38. Wang Meng, "Duobi zonggao" (Fleeing the sublime), Dushu, January 1993. Available online at: http://reading.cersp.com/WeekReading/Extended/200603/1137.html (6/10/2010).

39. Wang Hui, "Dangdai Zhongguo sixiang zhuangkuang yu xiandaixing de weiji" (State of contemporary Chinese thought and the modernity crisis of modernity), quoted by Gloria Davies, Worrying About China: The Language of Chinese Critical Inquiry, Cambridge Mass., Harvard University Press, 2007, p. 63.

40. "Symposium: Ideology and Theory in the Study of Modern Chinese Literature: Paradigmatic Issue in Chinese Studies," Modern China, vol. 19, no. 1, January 1993.

41. Xu Ben, Disenchanted Democracy: Chinese Cultural Criticism After 1989, Ann Arbor, University of Michigan Press, 1999. See in particular Chapter 3: "The Postmodern-Postcolonial Stimulus and the Rise of Chinese Post-ist Theory," pp. 88 sq.

42. Cloria Davies, Worrying about China, op. cit., p. 116

43. Peter Hays Gries, China's New Nationalism, Berkeley, University of California Press, 2004.

44. It was Zhao Yiheng who first coined the term Houxue, "Post studies," "post-isms," and "postology," in an article published in no. 27 of Ershiyi shiji (February 1995): "Houxue yu Zhongguo xin baoshouzhuyi" (Postology and new conservatism in China). The term covers rather well, and not without a pinch of humour, postcolonial and postmodern discourse as well as deconstruction and debates on post-socialism, the post "New era," and post-totalitarianism. The term has been handed down to us and can now be said to have entered everyday speech.

45. Zhang Yiwu, "Chanshi Zhongguo de jiaolü" (The anxiety of interpreting China), Ershiyi shiji, no. 28, April 1995.

46. Edward L. Davis (ed.), Encyclopedia of Contemporary Chinese Culture, New York, Routledge, 2005, pp. 482-3.

47. For example: Xu Ben, in "Disanshijie piping zai dangdai zhongguo de chujing" (State of Third-World criticism in China today), Ershiyi shiji, no. 27, February 1995.

48. An Asian counterpart to François Cusset's classic (French Theory, La Découverte, 2003) that would give an account of the impact of literary, philosophical, and social theories on the Chinese intellectual and political world has yet to be written. It is a journey that would take us from the innovative experiences of Yue Daiyun, starting in 1980, to the translations of Fredric Jameson's lectures of 1985-86 by Tang Xiaobing and Zhang Xudong, future pupil and disciple of Arif Dirlik, specialist in the history of the Communist movement and an informed connoisseur of Chinese postisms. Yue Dayun's "On Western Literary Theory in China" can be found in Cloria Davis, op. cit., 2001, pp. 109-23.

49. Zhang Yinde, "Orient-Extrême: la réinterprétation en Chine des théories postcoloniales" (Far East: The reinterpretations in China of postcolonial theories), Revue de littérature comparée, Paris, éditions Klincksieck, no. 297, 2001/1.

50. The unabridged version of Orientalism (Vintage Books, 1978; Seuil, 1978) was not translated in its entirety into Chinese under the title Dongfangxue until 1999, published by Sanlian shudian, Beijing.

51. Xu Ben, Disenchanted Democracy, op. cit., Chapter 4, "The Anxiety of Cross Cultural Theorizing," pp. 129 sq. 
the traumas of 1989 around sometimes irreconcilable positions, challenging Marxist and Confucian ideological heritage just as much as the "proWestern" liberal opinions of the 1980s. It was in this new language that the players of the New Left, the defenders of liberalism, and contemporary promoters of revived Confucianism expressed themselves. These three events - contemporary, interwoven, and permeable - dramatically transformed the nature and language of Chinese studies, enriching debates with a theoretical textuality that was by and large imported and relayed through the pages of Ershiyi shiji.

It must be added here that the impact of the market and Capitalist globalisation, which provided a new backdrop to these ruptures, was no less a revolution. This decisive change gave birth not only to cultural relativism, the direct consequence of pragmatic and instrumental readings of the classics of the postcolonial canon, (52) but also to new, ambiguous forms of resistance, sometimes difficult to interpret in a process of clarifying an often ambiguous link with the West that is now finally removing China and the Chinese from its oscillation between the attraction and repulsion created by the hopes and frustrations born of the meeting with its cultural "Other." (53)

(4) Parallel to these developments, the journal also kept an eye on the economic and social developments that triggered the wave of economic liberation brought about in 1992 by Deng Xiaoping's (鄧小平 1904-1997) now famous Southern Inspection Tour (南巡 Nanxun). Most critics - economists, sociologists, and historians - discussed with particular passion the new social polarisation engendered in Chinese society by the reforms. This became evident in the late 1990s and gathered steam in the 2000s, to the point where it became the heart of social policy from 2002 onwards with the "small prosperity" (小康 - xiao kang) and "harmonious society" (和諧 社會 - hexie shehui) projects. ${ }^{(54)}$ The criticisms of the Ershiyi shiji authors with regard to these new concepts were severe. In particular there are the uncompromising observations of He Qinglian (何清漣 born in 1956) on the moral responsibility and social cost of the reforms, whether it be a question of the Chinese stock markets, (55) ownership rights, corruption, (56) or the financial crisis. ${ }^{(57)}$ One also thinks of the solutions that political scientists and economists as different as Wang Shaoguang (王紹光 born in 1954), Hu Angang (胡鞍鋼 born in 1953), and Cui Zhiyuan (崔之元 born in 1963) tried to provide for these problems in a special feature in the journal devoted to the debate on the "government's capacities" (國家能力 guojia nengli). ${ }^{(58)}$

(5) Lastly, Xu Youyu reminds us that Ershiyi shiji is the only journal published in China in which the memory of the traumatic events of the Cultural Revolution (1966-76) is regularly the subject of articles, special features, and anniversary issues. ${ }^{(59)}$ The former Red Guard knows what he is talking about when he says that:

The particular value of Ershiyi shiji lies in the fact that if China needs a forum for debate, when the intellectual community has no other choice than to create this arena elsewhere, the journal of the Chinese University of Hong Kong is there. It has offered those who think about China a precious arena in which to faithfully record the tortuous path of the world of Chinese thinking over the last 20 years. ${ }^{(60)}$

Finally, one might add that the very existence of this journal, and the metronomic regularity of its publication, invalidates somewhat the com- mon perception of a rupture between the years 1980 and 1990. Indeed, one might consider that Ershiyi shiji is prolonging the most positive aspects of the spirit of the Chinese Enlightenment of the 1980s. ${ }^{(61)}$ Its core value of intellectual diversity, the pluridisciplinary rigour of its content, and its desire to remain accessible to the greatest number of readers would seem to be an extension of the professionalisation movement begun in the late 1980s by mainland cultural activists. The latter had quickly understood that the intellectual dispersion characteristic of the period they had just lived through was not only of little constructive value, but above all potentially dangerous for any edifice constructed since the end of the 1970s. Ershiyi shiji therefore proved that a somewhat erratic period of nalaizhuyi (拿來主義 - "raptism") may be succeeded (from Hong Kong) in exemplary fashion by a journal that embodies rigour, curiosity, openness, and pluralism. ${ }^{(62)}$

\section{The 2000s - Normalisation of the intellectual world?}

The current prospect of a certain degree of stability in the Chinese intellectual scene is the direct result of the period of crisis in meanings we have just discussed. It is certainly now possible to speak of a form of normalisation of the intellectual exchanges resulting from this intense restructuring, in the 1990s, of a vast number of crisis situations (postmodernity, postsocialism, post "New Era," etc.). Progressively, the positions and trends became clear, and a new consensus emerged in the 2000s based on three new paradigms, recently analysed in detail by anthropologist Joël Thoraval. (63)

Firstly, the return of Confucianism in intellectual and political debates is now inevitable. The range of opinions on this question is extremely vast, however, ranging from the vision of Tang Yijie (湯一介 born in 1927), promoter of a low-key, modern, and potentially democratic doctrine, via that of Zhao Tingyang (趙汀陽 born in 1961), who would like to demonstrate

52. Zhou Xingjie, "Jinshinian Zhongguo houzhiminzhuyi piping zongshu" (Outline of postcolonial critique in the last ten years), Journal of the University of Yanshan, Xiangtan, vol. 4, no. 1, 2003.

53. On this point, besides Chen Yan's work (note 12), and Wang Chaohua's introduction, "Mind of the Nineties" (in Wang Chaohua (ed.), One China, Many Paths, London, Verso, 2003) that retraces the development of this major rupture of the 1990s, quoting freely from articles that appeared in the Hong Kong journal, one could, for a more detailed view, read Liu Kang's little book, Globalization and Cultural Trends in China, Honolulu, University of Hawaii Press, 2004, or the classic by Arlif Dirlik and Zhang Xudong (eds.), Postmodernism and China, London, Duke University Press, 2000. On the language of Chinese intellectuals and its subtleties, see Gloria Davies, Worrying About China: The Language of Chinese Critical Enquiry, op. cit.

54. "Creating a harmonious society," special issue of China Perspectives, $n^{\circ} .2007 / 3$.

55. Ershiyi shiji, no. 21, February 1994.

56. Ershiyi shiji, no. 29, June 1995.

57. Ershiyi shiji, no. 44, December 1997. Following the publication of her book Xiandaihua de xianjing (The trap of modernisation) (Jinri Zhongguo, 1998), He Qinglian was forced to leave China. She now lives in the United States.

58. Ershiyi shiji, no. 21, February1994.

59. Anniversary numbers, no. 36 and no. 37, August and September 1996, and no. 93, February 2006.

60. Xu Youyu, "Women xuyao zhege sixiang wenhua kongjian," art. cit. (note 27), p. 42.

61. Liu Qingfeng sees a more pragmatic continuity in the turnaround of certain activists after 1989. See: Liu Qingfeng, "Topography of Intellectual Culture in the 1990s: A Survey," in Cloria Davies, op. cit., 2001, pp. 47-69.

62. Nalaizhuyi is a principle (zhuyi) of appropriation (nalai) of foreign ideas with the sole aim of improving the Chinese situation. The term was invented by Lu Xun in 1934. There are several English translations: "raptism," "appropriatism," and "take-ism," among others. In French, the neologism "empruntisme" seems to fit quite well.

63. During a conference organised for the publication of no. 31 of the journal Extrême Orient/Extrême Occident, on 17 February 2010 at EHESS in Paris and available online at: http://www.rap.prd.fr/ ressources/detailVideo.php?fichier=ehess/cecmc/regard_sur_le_politique_en_chine.rm (19/05/2011). 
that the concept of Tianxia (天下 - everything under heaven) is the future of international relations, to the extremism of Jiang Qing (將慶 born in 1953), in favour of an antimodern, antidemocratic, and anti-Western traditionalism together with a utopic Royal Path (王道 - Wangdao) forged in a sublimated past. ${ }^{(64)}$

Secondly, ever since the challenges to the very idea of modernity - by Wang Hui (汪暉 born in 1959), Gan Yang, and Liu Xiaofeng (劉小楓 born in 1956) among others - we have been witnessing a widening of the historical perspective with the appearance of a new sense of the relationship to history, doubtless made possible by a little amnesia. The long and difficult departure from binarism - liberal Enlightenment against "feudal empire" offers new perspectives from which to approach Chinese history, from the longest to the most recent.

This change of historical perspective finally offers the possibility of a third standpoint, that of a new world perception that lays the foundation for a new relationship with the West. For example, on one end of the spectrum a Chinese, national cultural approach is emerging, of which Gan Yang may be considered a representative, ${ }^{(65)}$ whilst in the centre appears a liberal universalism that, although embattled, continues to deepen its imprint on society. Jin Guantao, Xu Youyu, Qin Hui (秦暉 born in 1953), Zhu Xueqin (朱學勤 born in 1952), and Xu jilin (許紀霖 born in 1957) are doubtless the most representative of this movement that survives despite a two fold confusion. Firstly, one associates these liberal intellectuals with the failure of the 1989 social movement and the "Westernist" fervour (西方主義 - xi- fangzhuyi) of the past decade. Secondly, they are frequently condemned in the name of the harmful social effects of economic (neo)liberalism. We can clearly understand the confusion - intentional and strategic - maintained by their opponents. ${ }^{(66)}$

Lastly, at the other end of the spectrum, we note the appearance of a radical, anticapitalist anti-globalization movement that advocates going beyond the nation-state, by rehabilitating, if need be, certain aspects of a hitherto irreclaimable Maoist past. Wang Hui is perhaps the best-known of the representatives of this critique who would like to move Chinese social protest closer to the movement against world economic neoliberalism born of the social excesses of capitalist globalisation, if need be by moving outside the traditional framework of analysis, generally of Western origin. ${ }^{(67)}$ This constitutes the third essential element in the consolidation of positions directly stemming from the debates of the preceding decade for which the pages of the Hong Kong journal were the theatre.

The exceptional richness of Ershiyi shiji, ${ }^{(68)}$ its acuity regarding the fundamental problems of Chinese transition, together with its permanent examination of the international situation enables us to foresee, without too much risk of being mistaken, a very bright future for the journal. It would therefore seem only natural for China Perspectives, founded at around the same time, to join in the celebration.

\section{ITranslated by Elizabeth Guill}

64. Jiang Qing, "Le confucianisme de la Voie royale: Direction pour le politique en Chine contemporaine" (The Confucianism of the "Royal Path" - Direction for politics in contemporary China), Extrême Orient, Extrême Occident, no. 31, Paris, PUV, October 2009. Almost all jiang Qing's writing can be found on the site "Confucius 2000": http://www.confucius2000.com/scholar/jiangqingwenji.htm (19/05/2011). Zhao Tingyang, "La philosophie du Tianxia" (The philosophy of Tianxia), Diogène, Paris, PUF, no. 221, pp. 4-25.

65. Gan Yang, "Prendre en compte la continuité historique pour penser le politique aujourd'hui" (Taking historical continuity into account when designing the politics of today), Extrême Orient/Extrême Occident, no. 31, October 2009.

66. Xu jilin, "Liangzhong minzhu de fansi pingheng - dui 'ziyouzhuyi' yu 'xinzuopai' lunzheng de fansi" (Balancing two sorts of democracy: Reflections on the polemics between liberalism and the New Left), in Liu Qing and Kwan Siu-chan (eds.), Ziyouzhuyi yu Zhongguo xiandaixing de sikao, (Reflections on liberalism and Chinese modernity), Hong Kong, CUHK Press, 2002, vol. 2, pp. 307-40.

67. For an overview of Wang Hui's critical work, see the introduction by Theodore Huters for the collection of texts he edited:Wang Hui, China's New Order - Society, Politics and Economy in Transition, Harvard Mass., Harvard University Press, 2003, pp. 3-39.

68. The list of the 42 members of the editorial committee is available on the journal's website: http://www.cuhk.edu.hk/ics/21c/index_g.htm (04/08/2011). Most of the names given in this article are on it. 